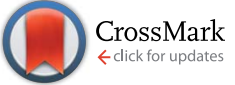

Cite this: RSC Adv., 2014, 4, 61743

\title{
Synthesis of nanostructured chitin-hematite composites under extreme biomimetic conditions $\uparrow$
}

\author{
Marcin Wysokowski, ${ }^{a}$ Mykhailo Motylenko, ${ }^{\mathrm{b}}$ Juliane Walter, ${ }^{c}$ Grzegorz Lota, ${ }^{\mathrm{d}}$ \\ Jarostaw Wojciechowski, ${ }^{d}$ Hartmut Stöcker, ${ }^{c}$ Roberta Galli, ${ }^{e}$ Allison L. Stelling, ${ }^{f}$

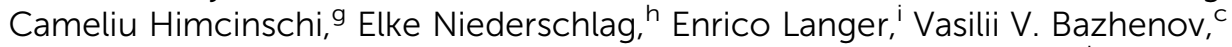 \\ Tomasz Szatkowski, ${ }^{a}$ Jakub Zdarta, ${ }^{a}$ Iaroslav Pertenko, ${ }^{c}$ Zoran Kljajić, \\ Tilmann Leisegang, ${ }^{k}$ Serguei L. Molodtsov, ${ }^{\text {clm }}$ Dirk C. Meyer, ${ }^{c}$ Teofil Jesionowski ${ }^{a}$ \\ and Hermann Ehrlich*c
}

Chitin of poriferan origin is a unique and thermostable biological material. It also represents an example of a renewable materials source due to the high regeneration ability of Aplysina sponges under marine ranching conditions. Chitinous scaffolds isolated from the skeleton of the marine sponge Aplysina aerophoba were used as a template for the in vitro formation of $\mathrm{Fe}_{2} \mathrm{O}_{3}$ under conditions $\left(\mathrm{pH} \sim 1.5,90^{\circ} \mathrm{C}\right)$ which are extreme for biological materials. Novel chitin- $\mathrm{Fe}_{2} \mathrm{O}_{3}$ three dimensional composites, which have been prepared for the first time using hydrothermal synthesis, were thoroughly characterized using numerous analytical methods including Raman spectroscopy, XPS, XRD, electron diffraction and HR-TEM. We demonstrate the growth of uniform $\mathrm{Fe}_{2} \mathrm{O}_{3}$ nanocrystals into the nanostructured chitin substrate and propose a possible mechanism of chitin-hematite interactions. Moreover, we show that composites made of sponge chitin- $\mathrm{Fe}_{2} \mathrm{O}_{3}$ hybrid materials with active carbon can be successfully used as electrode materials for electrochemical capacitors.

Received 8th September 2014 Accepted 11th November 2014

DOI: $10.1039 / c 4 r a 10017 d$

www.rsc.org/advances

\section{Introduction}

Extreme Biomimetics is a recently established and powerful approach for the synthesis of advanced nanostructured inorganic-organic materials with complex morphology, hierarchical organization and polymorphism. ${ }^{1-5}$ This new scientific direction is a milestone for modern biological materials inspired chemistry: especially in aspects where there is massive interest in the combination of various inorganic structures (i.e. nanocrystals, nanoparticles) with biological macromolecules. These unique combinations can be used for synthesis of novel functional materials used in tissue engineering, drug delivery systems, photonics, biosensors, catalysts and electrochemistry. $^{6-9}$ In contrast to traditional aspects of biomimetic synthesis of biominerals, Extreme Biomimetics is based on mineralization of various biomolecules under conditions which mimic extreme aquatic niches like hydrothermal vents, or hot springs. Therefore, the basic principle of this concept is to use biopolymers which are chemically and thermally stable under these specific conditions in vitro. Selection and application of such biomacromolecules plays a crucial role in the nucleation, thermodynamic and kinetic crystal growth; and can also be used as a soft template for inorganic structures. ${ }^{\mathbf{1 0 , 1 1}}$ There are plenty of examples of biomineralization phenomena in hot springs and hydrothermal vents in Nature (see for review ${ }^{\mathbf{1 2 - 1 4}}$ ). These niches with extreme conditions favor polysaccharides as 
templates for biomineralization, as most proteins and peptides are denatured by high temperature $\left(90^{\circ} \mathrm{C}\right)$ or low $\mathrm{pH}(\sim 1.5) . .^{12,13}$ The large number of reactive groups, differing chemical compositions, structures and functionalities characteristic for polysaccharides make them common nucleating and templating agents in living cells. ${ }^{15-18}$ It is reported that exopolysaccharides ${ }^{\mathbf{1 9 , 2 0}}$ from various gram positive and gram negative bacteria are able to capture $\mathrm{Fe}^{3+}$ ions from solution and induce precipitation of hematite $\left(\mathrm{Fe}_{2} \mathrm{O}_{3}\right)$ outside of the cell. This phenomenon protects the organisms from becoming encrusted with minerals. ${ }^{21}$

One of the most abundant polysaccharide involved in biomineralization is chitin. The outstanding mechanical properties of chitin ${ }^{22}$ play a very important role in Nature, where it is the main structural material that conveys stiffness and mechanical stability to the hard structures of arthropod cuticles ${ }^{23}$ mollusc shells, ${ }^{24,25}$ gastropod operculi, ${ }^{26}$ cuttlebones, ${ }^{27,28}$ diatoms, ${ }^{29}$ corals $^{30}$ and sponges. ${ }^{31-41}$ Thus, chitin and its derivatives are heavily investigated polysaccharides with regard to in vitro biomimetic mineralization. This includes calcification, ${ }^{\mathbf{1 1 , 4 2 - 4 4}}$ silicification ${ }^{\mathbf{4 , 4 5 - 4 7}}$ as well as structural biotemplating for the formation of $\mathrm{ZnO},{ }^{2,48} \mathrm{ZrO}_{2},{ }^{1,3} \mathrm{TiO}_{2}{ }^{49}$ and magnetite. ${ }^{50}$ Chemically, chitin is a linear polysaccharide composed of oxygen-containing hexose rings with an acetamido group at the second carbon position, linked together by $\beta$-1,4-glycosidic bonds. ${ }^{51,52}$ From the materials science point of view, chitin has a number of interesting properties which make it suitable for the development of bone substitutes, ${ }^{36}$ drug delivery systems, ${ }^{53}$ biosensors, and adsorbents and wound dressing materials. ${ }^{36,51,54}$ Additionally, chitin has high thermal stability up to $360{ }^{\circ} \mathrm{C} .{ }^{55-57}$ This thermostability is the key factor for the development of a new generation of biomaterials at high temperatures according to Extreme Biomimetics concepts. ${ }^{1-3}$

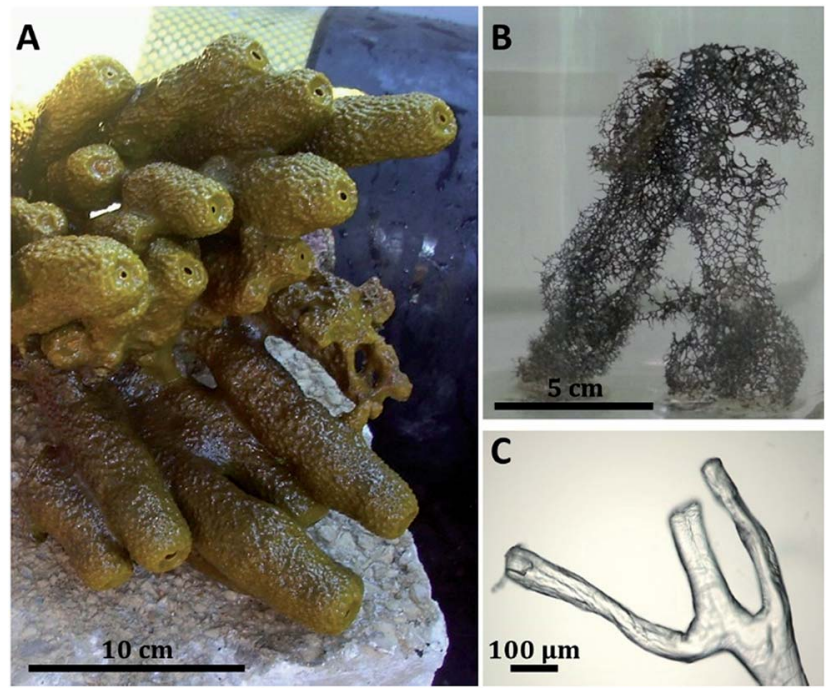

Fig. 1 Freshly collected marine sponge $A$. aerophoba with the fingerlike bodies about $2 \mathrm{~cm}$ in diameter (A), are a renewable source for obtaining the 3D skeletal structures (B), which, consequently, are source of pure chitinous tube-like fibres isolated after the special alkali treatment (C).
Hematite is the most thermochemically stable iron oxide under ambient conditions. ${ }^{58}$ Additionally, $\alpha-\mathrm{Fe}_{2} \mathrm{O}_{3}$ is an environmental friendly material which is characterized by small band gap, ${ }^{59}$ as well as unique electrical ${ }^{60}$ and catalytic properties. ${ }^{59}$ All these properties make hematite suitable for wide spectrum of applications, including sensors, ${ }^{61,62}$ catalysts for water splitting ${ }^{59,63}$ and for chemical reactions, drug delivery systems, ${ }^{64}$ pigments and batteries. Numerous combinations of various biomacromolecules like chitosan, ${ }^{65,66}$ silk $^{67}$ and cellulose ${ }^{68}$ with iron oxides are intensively studied. Recently, the development of a simple collagen/iron oxide material for potential applications in tissue engineering and imaging by crosslinking collagen to starch capped $\alpha-\mathrm{Fe}_{2} \mathrm{O}_{3}$ nanoparticles was reported. ${ }^{69}$ These starch capped nanoparticles were found to be nontoxic to fibroblast cells and were thus used for developing novel collagen constructs.

Peng et al. ${ }^{50}$ proved that chitin isolated from butterfly wings can be used as a 3D structural template for the development of hematite replicas with magnetophotonic properties using a sol-gel method followed by calcination. However, to the best of our knowledge, chitin-hematite materials prepared using hydrothermal route have not been reported before. Thus, in this study we decided to develop a $\mathrm{Fe}_{2} \mathrm{O}_{3}$-containing hybrid material using three-dimensional tube-like fibrous $\alpha$-chitin scaffolds for the first time. These were isolated from marine demosponge Aplysina aerophoba ${ }^{35}$ (Fig. 1), and served as a new organic template under hydrothermal synthesis conditions. We selected this very special organic matrix because threedimensional chitin-based scaffolds isolated from sponges (Porifera) are principally the promising candidates for practical applications in tissue engineering, catalysis, enzyme immobilization, etc. ${ }^{\mathbf{3 6}}$ Additionally, application of these morphologically defined skeletal networks from Nature overcomes challenges associated with the prefabrication of chitin into three-dimensional structures.

\section{Experimental}

The marine sponge Aplysina aerophoba (Aplysinidae: Verongida: Demospongiae: Porifera) was collected in the Adriatic Sea (Kotor Bay, Montenegro) in August 2008 by SCUBA diving. Due to the regeneration capacity of $A$. aerophoba, divers only cut the apical parts of the sponge body. The basic parts were remain intact and can regenerate under natural conditions. Sponge samples were put in ziplock bags underwater, brought back to the laboratory at Institute of Marine Biology (Kotor, Montenegro) and frozen less than $1 \mathrm{~h}$ after collection. The sponge fragments as collected were prepared, lyophilized and transported by the INTIB GmbH (Germany) to the Laboratory of Biomineralogy \& Extreme Biomimetics Group, TU Bergakademie Freiberg (Germany). Iron(III) chloride (no. 157740) and was obtained from SigmaAldrich (Germany). The $\alpha$-chitin standard from A. aerophoba was prepared according to a previously described method ${ }^{35}$ by INTIB GmbH (Germany). 


\section{Hydrothermal synthesis of chitin- $\mathrm{Fe}_{2} \mathrm{O}_{3}$ composites}

In a typical experiment, hydrothermal deposition of $\mathrm{Fe}_{2} \mathrm{O}_{3}$ on a chitinous template was performed by the forced hydrolysis of iron(III) chloride. ${ }^{70-72}$ In brief, $0.3 \mathrm{~g}$ of anhydrous $\mathrm{FeCl}_{3}$ was dissolved in $10 \mathrm{ml}$ of ultra-pure water. Afterwards the solution was added to a mixture containing $90 \mathrm{ml}$ of ultra-pure water and $0.75 \mathrm{ml}$ of $1 \mathrm{M} \mathrm{HCl}$. In the next step, sponge chitin fragment (1 $\times 0.5 \mathrm{~cm}$ ) was added to the solution and the whole volume was transferred into a Teflon-lined vessel $(200 \mathrm{ml})$ of the hydrothermal reactor (Parr, USA), and heated to $90{ }^{\circ} \mathrm{C}$ for $48 \mathrm{~h}$. After this time, the chitin template covered with $\mathrm{Fe}_{2} \mathrm{O}_{3}$ nanocrystals was carefully isolated, washed with distilled water in an ultrasound bath (Elmasonic $\mathrm{GmbH}$, Germany) for $20 \mathrm{~min}$, brought up to $\mathrm{pH} 6.8$ and dried at $90{ }^{\circ} \mathrm{C}$ for $48 \mathrm{~h}$ (Memmert incubator, Germany). Fragments of chitin- $\mathrm{Fe}_{2} \mathrm{O}_{3}$ were disrupted mechanically using liquid nitrogen and an agate mortar to obtain nanosized powder that was used for HR-TEM studies. As a control, $\mathrm{Fe}_{2} \mathrm{O}_{3}$ particles were also prepared within the same reaction system without the presence of any chitin templates.

\section{Scanning electron microscopy (SEM)}

The surface morphology and microstructure of the chitinous scaffolds of sponge origin before and after $\mathrm{Fe}_{2} \mathrm{O}_{3}$ deposition were examined using SEM images recorded with an Ultra 55 microscope (Carl Zeiss AG, Germany). Before testing, the samples were coated with carbon over a period of $45 \mathrm{~s}$ using an Edwards S150B sputter coater.

\section{High resolution transmission electron microscopy (HRTEM)}

The samples for the TEM investigation were prepared by the standard route, which includes the following steps: a drop of the water suspension containing the nanoparticulated sample was placed on the electron microscopy grid of copper (Plano $\mathrm{GmbH}$, Wetzlar, Germany), covered with a perforated carbon film and afterwards dried in air.

Different microstructure parameters such as crystallinity, crystallite size and shape, (local) preferred orientation of $\mathrm{Fe}_{2} \mathrm{O}_{3}$ crystallites in the local regions of chitin- $\mathrm{Fe}_{2} \mathrm{O}_{3}$ materials, were investigated and analysed by using of the selected area electron diffraction (SAED), high resolution TEM (HRTEM) and energy dispersive X-ray (EDX) methods. These investigations were done using analytical TEM JEM-2200FS of JEOL, which was operated with $200 \mathrm{kV}$ acceleration voltage and equipped with a $C_{\mathrm{s}}$-corrected illumination system, an ultra-high resolution (UHR) objective lens $\left(C_{\mathrm{s}}=0.5\right)$ and an in-column filter. For the recording of micrographs and diffraction pattern a $2 \mathrm{k} \times 2 \mathrm{k}$ CCD-camera by Gatan Inc. was used, meanwhile the EDX spectra and maps with energy dispersive X-ray analyser from JEOL were evaluated.

The analysis of diffraction pattern and Fast Fourier Transformed (FFT) HRTEM-images was done by using of DigitalMicrograph software of Gatan Inc. taking into account the inverse interlattice plane distances and angles between lattice planes to obtain the orientation of crystallites.

\section{Raman spectroscopy}

Raman spectra were recorded using a Raman spectrometer (RamanRxn1 ${ }^{\mathrm{TM}}$, Kaiser Optical Systems Inc., USA) coupled to a light microscope (DM2500 P, Leica Microsystems GmbH, Germany), additional Raman measurements have been performed, for details see ESI. $\dagger$

\section{X-ray diffraction}

X-ray diffraction (XRD) was carried out on a Bruker D8 Advance in Bragg-Brentano geometry using $\mathrm{Cu}-\mathrm{K} \alpha$ radiation provided by a secondary graphite monochromator. The samples were placed on rotating stainless steel holders without adding additional chemicals.

\section{X-ray photoelectron spectroscopy}

XPS analyses were performed using a ESCALAB 250Xi from Thermo Scientific, with a monochromatic Al K $\alpha$ X-ray source $(1486.6 \mathrm{eV})$. The X-ray source has a spot size of $650 \mu \mathrm{m}$ and operates at a power of $14.8 \mathrm{kV}$ and $19.2 \mathrm{~mA}$. The spectra were taken with a pass energy of $20 \mathrm{eV}$ and an energy step width of 0.1 $\mathrm{eV}$. The base pressure was $2 \times 10^{-10}$ mbar but during the measurement the pressure increased to $3 \times 10^{-7} \mathrm{mbar}$ due to the ion gas flow from the flood gun, which was used for charge compensation.

\section{Electrochemical measurements}

Electrochemical characterization was performed in a two electrode Swagelok® system. The composition of pellets was: 85 $\mathrm{wt} \%$ of active materials, $10 \mathrm{wt} \%$ of polyvinylidene fluoride (PVDF Kynar Flex 2801) and 5 wt\% of acetylene black. The active materials used were commercially available activated carbon Norit@ DLC Supra 30 (S30) with a surface area of $1588 \mathrm{~m}^{2} \mathrm{~g}^{-1}$, chitin- $\mathrm{Fe}_{2} \mathrm{O}_{3}$ hybrid material $(\mathrm{Ch}-\mathrm{H})$ and a mixture of $80 \%$ activated carbon Norit@ DLC Supra 30 with $20 \%$ of the chitin$\mathrm{Fe}_{2} \mathrm{O}_{3}$ hybrid material (Ch-H $\left.(20 \%)+\mathrm{S} 30(80 \%)\right)$. The masses of the electrodes were in the range of $7-9 \mathrm{mg}$ and a geometric surface area of one electrode was $0.8 \mathrm{~cm}^{2}$. As an electrolyte, 6 mol $\mathrm{l}^{-1} \mathrm{KOH}$ was used. The capacitance properties of the materials (expressed per mass of one electrode) were estimated by galvanostatic charge/discharge $\left(100 \mathrm{~mA} \mathrm{~g}^{-1}-1000 \mathrm{~mA} \mathrm{~g}^{-1}\right)$, cycling voltammetry $\left(\mathrm{CV} ; 1-100 \mathrm{mV} \mathrm{s}^{-1}\right)$ and electrochemical impedance spectroscopy (100 kHz to $1 \mathrm{mHz}$ ) using VSP Biologic, France.

\section{Results and discussion}

The presented SEM images (Fig. 2) indicate that using the $\alpha$ chitin from the sponge $A$. aerophoba as a structural template during hydrothermal formation of iron oxide leads to the formation of chitin- $\mathrm{Fe}_{2} \mathrm{O}_{3}$ composites. They are homogeneously covered, with uniform, spherical nanoparticles of hematite as confirmed below using different analytical methods. It can also be observed that iron oxide nanocrystals are so tightly bonded to the chitinous substrate that they cannot be removed from its surface, even after the ultrasound-assisted 

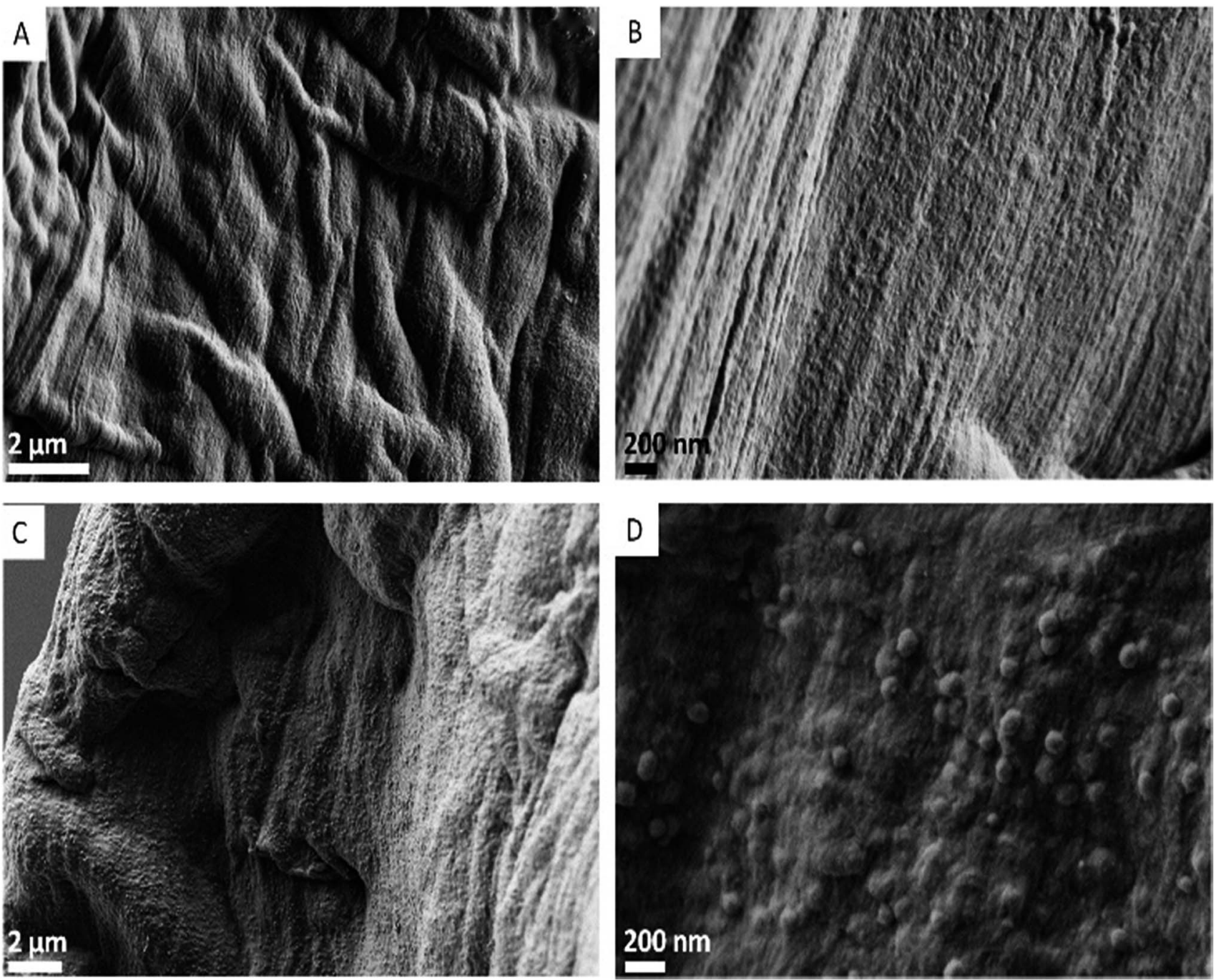

Fig. 2 SEM images of the surface of the isolated $A$. aerophoba chitinous scaffold before $(a$ and $b)$ and after (c and d) hydrothermal reaction with respect to obtaining the hematite crystals.

washing procedure. The nanomorphology of the $\mathrm{Fe}_{2} \mathrm{O}_{3}$ crystals, which were grown on chitin, is also similar to those, which were prepared without template (see Fig. S1 ESI†). Therefore, it is assumed that chitin does not have an influence on principal oval morphology of hematite nanocrystals. However, as we will report below, chitin plays a specific role in the regulation of the size of hematite nanoparticles.

The morphology of nanostructured chitin- $\mathrm{Fe}_{2} \mathrm{O}_{3}$-composite, which consists of chitin-nanofiber with oval nanoparticles of $\mathrm{Fe}_{2} \mathrm{O}_{3}$, is also quite visible using TEM (Fig. 3).

These nanoparticles are especially clearly visible in the dark field image (Fig. 3B). The size of the $\mathrm{Fe}_{2} \mathrm{O}_{3}$-particles ranges between 50 and $100 \mathrm{~nm}$.

The analysis of the region of interest (ROI, Fig. 3C) by the combination of scanning TEM (STEM) and EDX-measurements and evaluation of EDX-mapping (Fig. 3D) showed the high concentrations of iron and oxygen in the nanoparticles. The increase in concentration of the corresponding elements toward the center of the nanoparticle means that the particles have a spherical shape. In addition, this shows the local point analysis (Fig. 3E) in the region of chitin, the increased concentration of potassium, which originate from the chitinous lamella.

We used several analytical methods (electron diffraction and HRTEM, XRD, Raman, XPS) to confirm the presence of hematite within chitin-based composite obtained in the study.

Detailed local analysis of individual $\mathrm{Fe}_{2} \mathrm{O}_{3}$ particles by HRTEM (FFT) and SAED has shown that these are mainly monocrystalline with different random orientations (Fig. 4). The indexed FFT from the HRTEM micrograph (Fig. 4B) shows a particle with a [152] zone axis. The contrast of HRTEM images is caused by nearby spherical shape of the particle. Another two particles have an $[\overline{4} \overline{1} \overline{1}]$ and slightly tilted $[\overline{2} \overline{1} \overline{1} \overline{1}]$ orientations (the selected area aperture overlaps two particles), which are indexed with yellow and pink text respectively (Fig. 4C).

The XRD patterns of the prepared chitin- $\mathrm{Fe}_{2} \mathrm{O}_{3}$ composites, $\alpha$-chitin standard from $A$. aerophoba, and $\alpha-\mathrm{Fe}_{2} \mathrm{O}_{3}$ references are shown in Fig. 5. The obtained spectra for chitin- $\mathrm{Fe}_{2} \mathrm{O}_{3}$ perfectly 

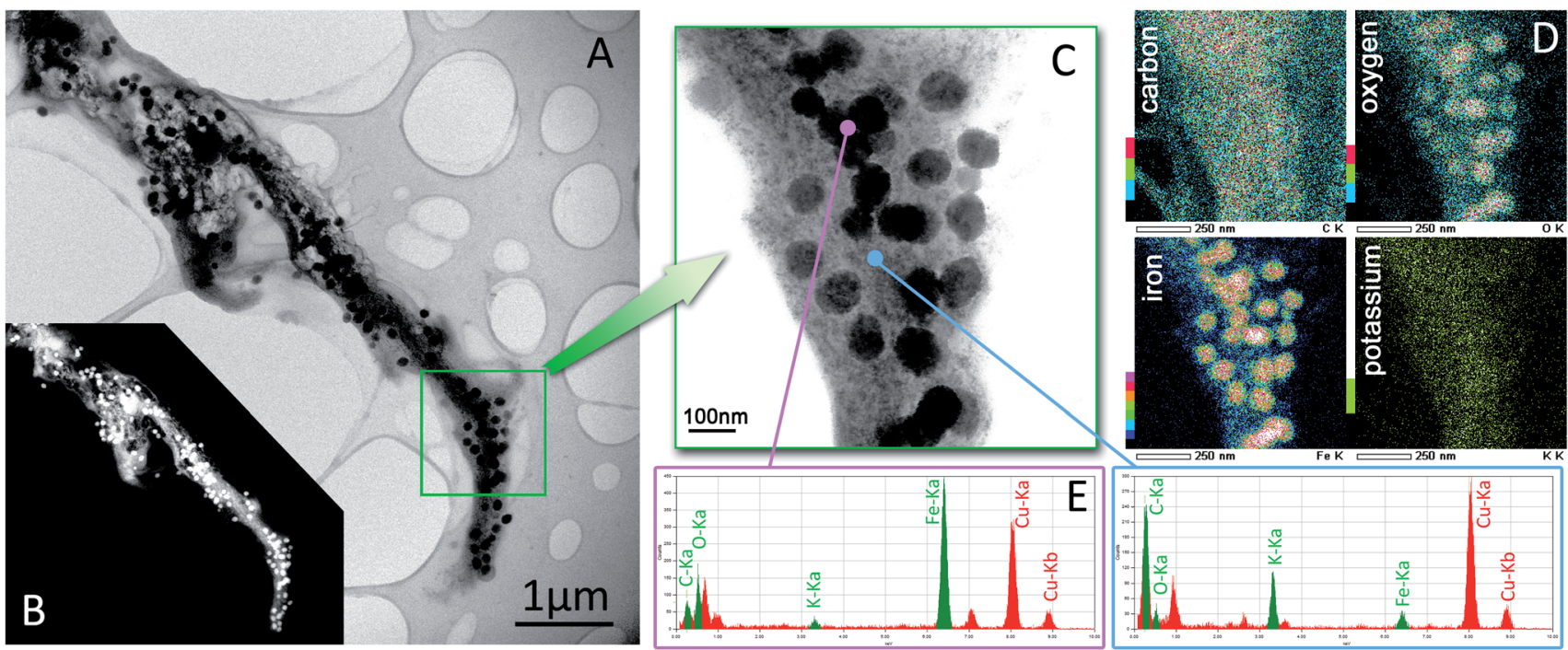

Fig. 3 TEM investigations. Bright-field (A) and dark-field (B) images of the chitin- $\mathrm{Fe}_{2} \mathrm{O}_{3}$-composite on graphitic template and the results of elemental analysis of ROI (C) by EDX-mapping (D) and local EDX-measurements (E).

match the $\alpha-\mathrm{Fe}_{2} \mathrm{O}_{3}$ (hematite) reference (according to 33-664 JCPDS card). Rietveld refinement of these data reveals that the hematite reference sample, obtained without presence of chitin, exhibits crystallites with typical sizes of $74.7 \pm 2.1 \mathrm{~nm}$. The size of hematite crystallites on the chitin is $54.3 \pm 5.2 \mathrm{~nm}$, and thus our obtained data closely reflect the HRTEM results.

The size of the hematite nanoparticles grown upon the chitinous substrate fluctuates between $50-100 \mathrm{~nm}$. This is in accordance with results from Raman spectroscopy (Fig. 6).

It has been reported ${ }^{73}$ that the Raman shift of peaks characteristic for hematite strongly depends on particle size. The
Raman spectra for $\alpha-\mathrm{Fe}_{2} \mathrm{O}_{3}$ reference nanoparticles, $\alpha$-chitin standard from $A$. aerophoba and chitin- $\mathrm{Fe}_{2} \mathrm{O}_{3}$ composite materials are shown in Fig. 6 and S2 ESI, $\uparrow$ respectively. The Raman spectrum of $\alpha-\mathrm{Fe}_{2} \mathrm{O}_{3}$ nanoparticles show all the characteristic hematite bands which belong to the $D_{3 d}{ }^{6}$ space group: two $\mathrm{A}_{1 \mathrm{~g}}$ modes $\left(224 \mathrm{~cm}^{-1}\right.$ and $\left.494 \mathrm{~cm}^{-1}\right)$ and five $\mathrm{E}_{\mathrm{g}}$ modes (at 245 $\mathrm{cm}^{-1}, 289 \mathrm{~cm}^{-1}$, shoulder at $\left.298 \mathrm{~cm}^{-1}, 407 \mathrm{~cm}^{-1}, 608 \mathrm{~cm}^{-1}\right) \cdot{ }^{73,74}$ The presence of several characteristic bands at 255, 323, 368, $395,457,501,648$, and $710 \mathrm{~cm}^{-1}$ which correspond to $\delta$ (CCC) ring deformation ${ }^{75}$ in the Raman spectrum of isolated chitin

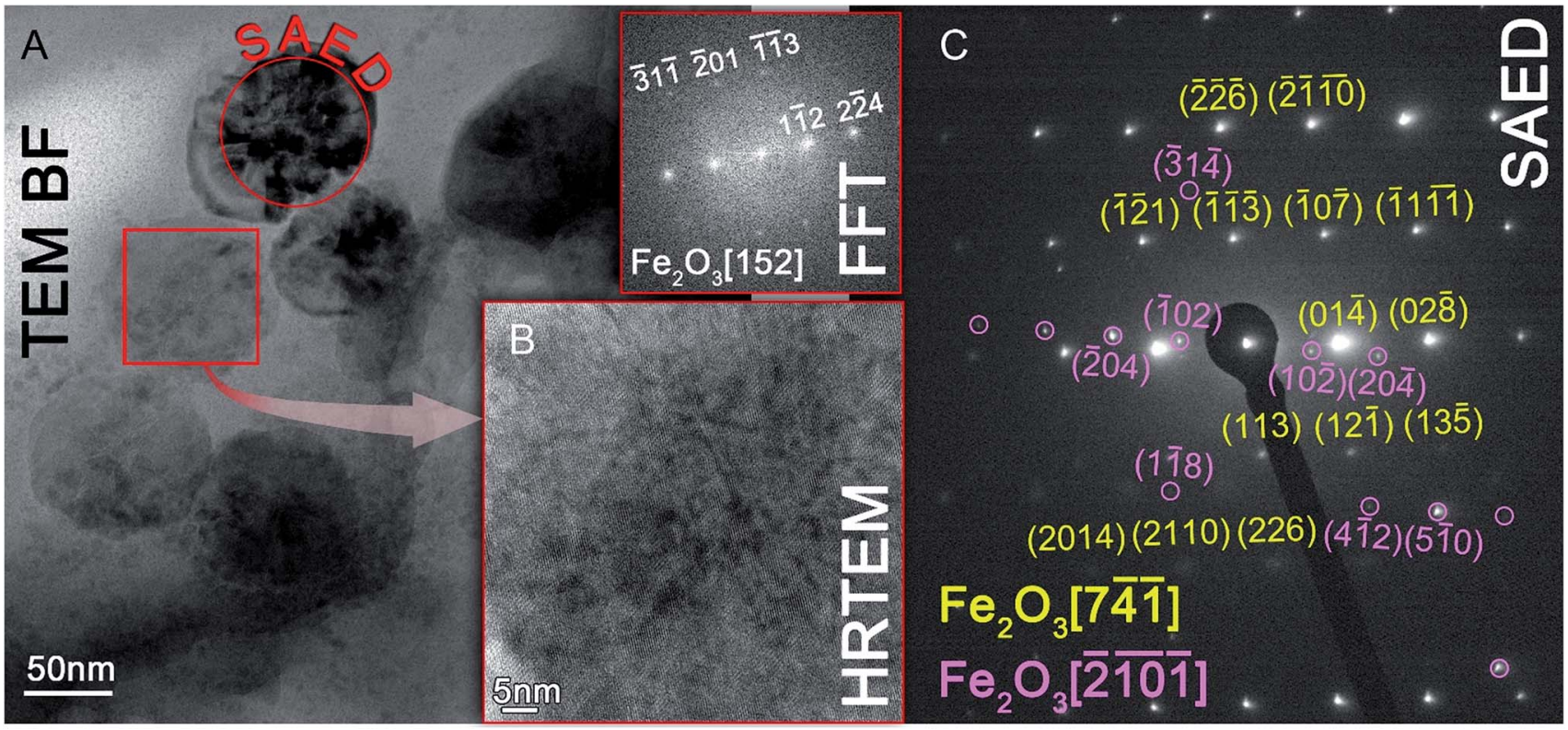

Fig. 4 Detailed analysis of orientation of hydrothermal obtained $\mathrm{Fe}_{2} \mathrm{O}_{3}$-particles on sponge chitin (A) by evaluation of $\mathrm{HRTEM}$ micrograph (B) and SAED pattern (C) 


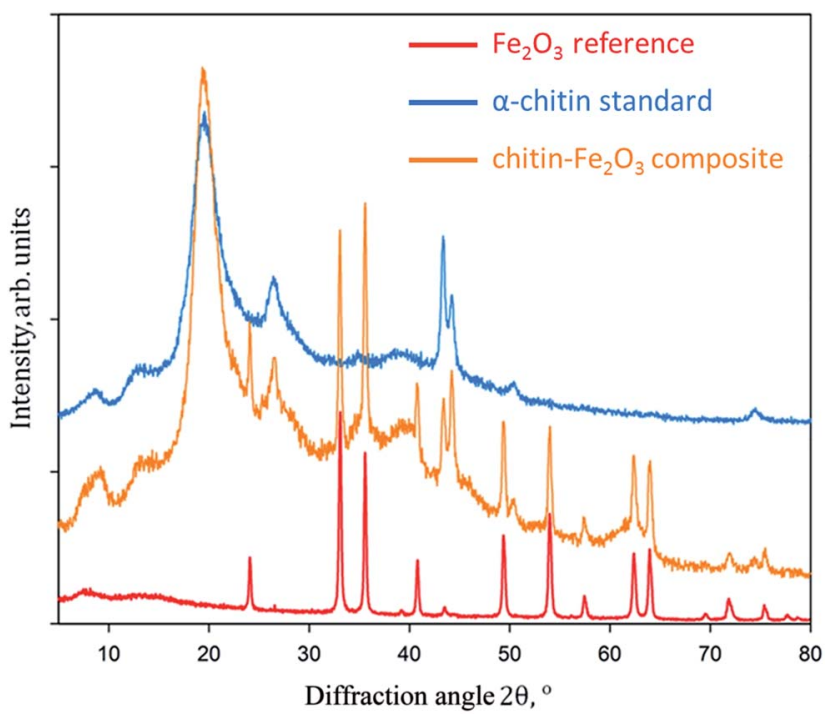

Fig. 5 XRD pattern of $\alpha$-chitin from $A$. aerophoba, hematite and obtained chitin- $\mathrm{Fe}_{2} \mathrm{O}_{3}$ composite.

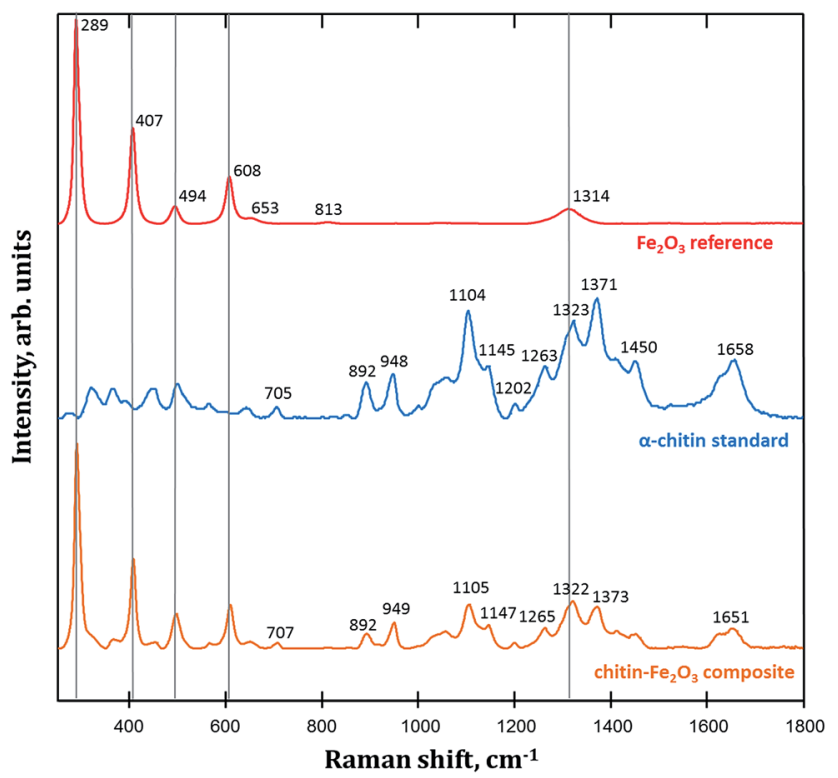

Fig. 6 Raman spectra of $\alpha$-chitin standard from A. aerophoba, hematite and the obtained chitin- $\mathrm{Fe}_{2} \mathrm{O}_{3}$ composite.

(Fig. S2 ESI $\dagger$ ) additionally reveals that it is $\alpha$-chitin polymorph. ${ }^{31,34}$

The Raman spectra of the obtained chitin- $\mathrm{Fe}_{2} \mathrm{O}_{3}$ composites show the presence of four very intense peaks characteristic of hematite (vertical lines). It is known ${ }^{76}$ that the position and width of the hematite nanoparticles peaks at $226 \mathrm{~cm}^{-1}$ and $412 \mathrm{~cm}^{-1}$ (Fig. S2 ESI $\dagger$ ) are influenced by the nanoparticles' dimensions. According to this, from the obtained chitin- $\mathrm{Fe}_{2} \mathrm{O}_{3}$ spectra we can estimate a dimension of $80-100 \mathrm{~nm}$ for the particles, in agreement with SEM results. Because of the clearly visible deformations of $-\mathrm{NH}$ and $\mathrm{C}=\mathrm{O}$ bands in the Raman spectra of the chitin-hematite composite (Fig. 6), we suggest that these groups are interacting with $\mathrm{Fe}_{2} \mathrm{O}_{3}$.

The thermal behavior of chitin and chitin- $\mathrm{Fe}_{2} \mathrm{O}_{3}$ composite was determined by thermogravimetry and differential thermal analysis performed in an oxidative (air) atmosphere (Fig. S3 ESI $\dagger$ ). The TG curve of the $\alpha$-chitin scaffold indicates that the main thermal degradation of the biopolymer starts at $200{ }^{\circ} \mathrm{C}$ and ends at $618{ }^{\circ} \mathrm{C}$. The shape of the TG curve demonstrates that degradation in air occurs in two steps, and this result corresponds to thermal behaviors of $\alpha$-chitin isolated from crab shells, previously published by Georgieva et al. ${ }^{57}$ Thermogravimetric analysis proves that thermal decomposition of chitin$\mathrm{Fe}_{2} \mathrm{O}_{3}$ composite start at the same temperature, however it stops at $440{ }^{\circ} \mathrm{C}$. Moreover, the shape of the degradation curve clearly indicates that it is one-step process. Therefore we suggest that incorporation of hematite nanoparticles into the chitin matrix inhibits the second stage of chitin degradation and results in an increase of thermal stability of the composite material in comparison to the pure chitin reference.

Important data about the role of chitin and formation mechanism of chitin-hematite composites were obtained using the XPS analysis (Fig. 7). The best information about interactions between chitin and iron oxide is provided by the $\mathrm{O} 1 \mathrm{~s}$ peak from chitin-hematite composites. For example, the analysis of the results show subpeaks at $529.42 \mathrm{eV}$ and $527.65 \mathrm{eV}$, which are ascribed to $\mathrm{O}$ atoms of chitin bound to $\mathrm{Fe}$ in $\alpha-\mathrm{Fe}_{2} \mathrm{O}_{3}$ nanoparticles. ${ }^{77}$ Additionally, the peak at $531.70 \mathrm{eV}$ is assigned to -OH groups of chitin. It is worth noting that the intensity of this peak decreases in spectra from the chitin- $\mathrm{Fe}_{2} \mathrm{O}_{3}$ composite.

The Fe 2p peak of the chitin-hematite sample shows the presence of distinct subpeaks at 710.7 and $724 \mathrm{eV}$ (Fig. S4a ESI $\dagger$ ) and a satellite peak at around $718 \mathrm{eV} .^{78}$ The presence these peaks indicates that the iron is almost completely in the $\mathrm{Fe}^{3+}$ state. ${ }^{50,79}$ Additionally, the XPS N 1s peak (Fig. S4b ESI $\dagger$ ) was examined in detail to confirm the chemical state of nitrogen atoms present in the chitin and chitin-hematite materials. The



Fig. $7 \bigcirc$ 1s XPS spectrum for $\alpha$-chitin from A. aerophoba (blue line), hematite (red line) and chitin- $\mathrm{Fe}_{2} \mathrm{O}_{3}$ composite (orange line). 
observed profiles of the $\mathrm{N}$ 1s transition are virtually identical for both materials. They are both symmetrical with mixed Gaussian-Lorentzian profile shapes, and with a maximum at a binding energy of $398.8 \mathrm{eV}$. These obtained results using XPS spectroscopy indicate that $-\mathrm{OH}$ groups located in the chitin molecule plays a crucial role in the formation of chitin-hematite composites.

On the basis of the results presented in this work and previously reported studies realized with the chitinous butterfly wings ${ }^{50}$ and chitosan ${ }^{80,81}$ we propose a mechanism of formation and interactions between $\alpha$-chitin scaffold and hematite nanoparticles within chitin- $\mathrm{Fe}_{2} \mathrm{O}_{3}$ composite, as illustrated in Fig. 8. The model proposed is based on the formation of an $-\mathrm{O}-\mathrm{Fe}$ bond between chitin and hematite similar to the case described by Zhang et al. ${ }^{77}$ for PET-hematite composites. However, the presence of hydrogen bonds and the chelating effect ${ }^{82}$ between $\mathrm{C}=\mathrm{O}, \mathrm{NH}$ and $\mathrm{OH}$ groups of the chitin and iron oxide is also included.

The question about the possible practical applications of the chitin-hematite composites obtained is of immense importance. Consequently, we investigated the electrochemical properties of this novel composite material in two-electrode cells using an alkaline electrolyte for the first time.

Voltammetric characteristics at $10 \mathrm{mV} \mathrm{s}^{-1}$ are shown in Fig. 9a and differences in capacitances between the initial materials and composite are quite well visible. The capacitance of raw chitin- $\mathrm{Fe}_{2} \mathrm{O}_{3}$ hybrid material $(\mathrm{Ch}-\mathrm{H})$ is negligible. Active carbon (S30) with high surface area shows a regular rectangle shape of the CV curve and good charge propagation. Considerable increase of the capacitance is noticed for the $\mathrm{Ch}-\mathrm{H} / \mathrm{S} 30$ composite. The increase can be the result of both redox reactions of the chitin- $\mathrm{Fe}_{2} \mathrm{O}_{3}$ hybrid material in an alkaline electrolyte, and the developed surface area of the active carbon component. Table S1 ESI $\dagger$ illustrates the capacitance data obtained from different electrochemical methods.

The use of activated carbon $/ \mathrm{Fe}_{2} \mathrm{O}_{3}$-chitin composite in our work allows us to increase the capacitances of the electrochemical capacitor. This is due to the appearance of reduction and oxidation reactions on the electrodes. In this type of supercapacitor, the energy is stored in the electric double layer (active carbon) and from redox reactions $\left(\mathrm{Fe}_{2} \mathrm{O}_{3}\right.$-chitin composite). Adsorption/desorption processes of ions derived from the electrolyte occur in the pores of carbonaceous material, while in the pores of the nanostructured hematite deintercalation/intercalation processes occur. Furthermore, during the process of oxidation and reduction on the electrode, consisting of $\mathrm{Ch}-\mathrm{H} / \mathrm{S} 30$ composite, a reversible reaction ${ }^{83}$ appears:

$$
\mathrm{Fe}_{2} \mathrm{O}_{3}+\mathrm{OH}^{-} \leftrightarrow \mathrm{Fe}_{2} \mathrm{O}_{3} \mathrm{OH}+\mathrm{e}^{-}
$$

The analysis of electrochemical impedance spectroscopy is presented in Fig. 9b. The results exhibit the improvement of capacitance and charge propagation using the composite as electrode materials for an electrochemical capacitor. Moreover, as shown in Fig. 9c, materials display the considerable stability



Fig. 8 A schematic view on possible mechanism of chitin-hematite interactions under hydrothermal conditions. 

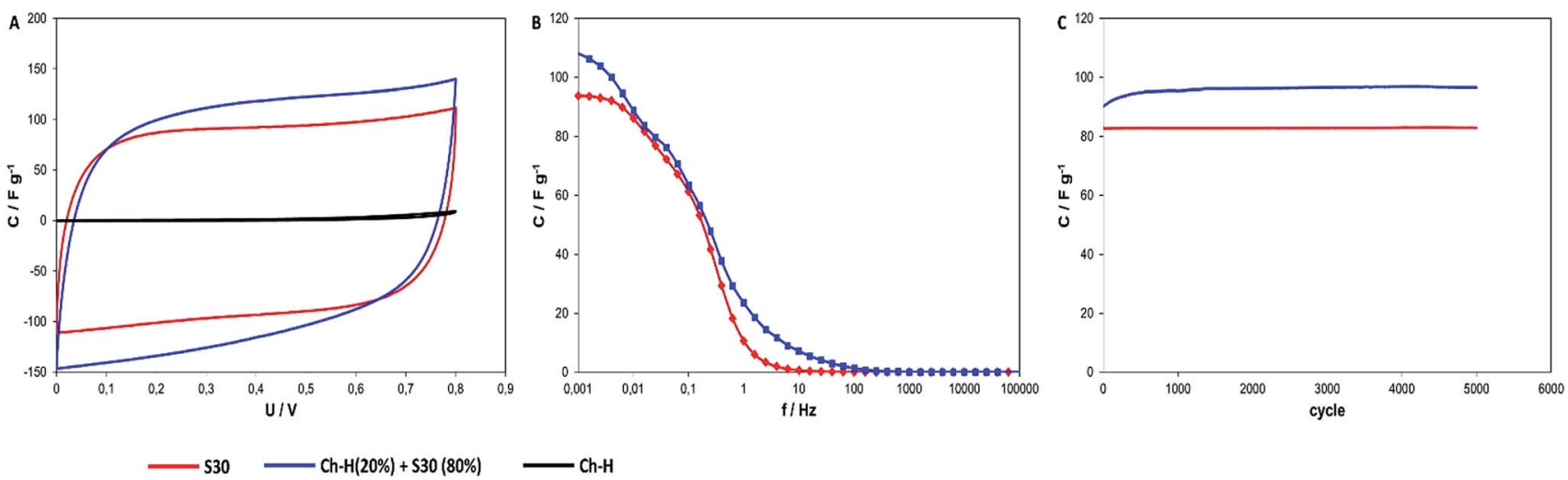

$=$ S30 - Ch-H $(20 \%)+\$ 330(80 \%) \quad-$ Ch-H

Fig. 9 (a) Cyclic voltammograms of S30, composite and $\mathrm{Ch}-\mathrm{H}$ at $10 \mathrm{mV} \mathrm{s}^{-1}$; (b) capacitance-frequency dependence for active carbon and composite; (c) cycling stability of active carbon and composite with current density $1 \mathrm{~A} \mathrm{~g}^{-1}$.

during cycling measurements. After 5000 cycles of galvanostatic charge/discharge with the current regime of $1 \mathrm{~A} \mathrm{~g}^{-1}$ the capacitance of active carbon decreased only negligibly - less than one percent. In the case of chitin- $\mathrm{Fe}_{2} \mathrm{O}_{3}$ hybrid material/active carbon composite, the increase of capacitance after cyclability measurements is observable.

Probably, a redox bioactive film is built on the surface of the composite and an increase of (pseudo)capacitance is observed. Stability during cycling measurements is a very important parameter for practical applications of materials for electrochemical capacitors.

\section{Conclusions}

The results presented and discussed in this work have shown that the hydrothermal route for development of novel chitinhematite composites is realistic. Chitin of poriferan origin is not only the a prospective thermostable biological material, but also represents an example of a renewable source due to high regeneration ability of Aplysina sponges under marine ranching conditions. It has been described that saccharides (for example, glucose) can be used in versatile fabrication of hierarchically nanostructured goethite with controlled morphologies from 1D unique architecture composed of arrayed nanoplates to 3D urchin-like superstructures. ${ }^{84}$ Moreover, this composite can be used as a precursor for the thermally-assisted $\left(300{ }^{\circ} \mathrm{C}\right)$ formation of hematite. The morphology resembles that of the urchin-like glucosegoethite composite, and is characterized by high specific surface area. In accordance to this method, our study proves that formation of hematite occurs at a temperature of $90{ }^{\circ} \mathrm{C}$ and yields a composite polysaccharide (in this case chitin) with hematite nanoparticles. Therefore, the unique feature of this method is that we obtained hematite nanostructures in one-step method - additional calcination or thermal treatment is not needed. Composites of sponge chitin- $\mathrm{Fe}_{2} \mathrm{O}_{3}$ hybrid material with active carbon could be successfully use as electrode materials for electrochemical capacitors. Using suitable composite components with different mechanisms of energy storage can provide improvement to the electrochemical properties of electrode materials. Additionally, according to recently published papers, the development of this facile method for combining biocompatible and biodegradable polymers with iron oxide opens new possibilities for the development of iron oxide-based materials for applications in supercapacitors, ${ }^{60,85}$ sensors, ${ }^{61,86}$ catalysts $^{59}$ and drug carriers for anticancer therapy ${ }^{64}$ Therefore, we believe that this presented study will affect a wide range of research associated with hematite-based biomaterials.

\section{Acknowledgements}

This work was partially supported by Research Grants for Doctoral Candidates and Young Academics and Scientists up to 6 months - DAAD Section 323-Project no. 50015537 and the following research grants: DFG Grant EH 394/3-1, PUT research grant 03/32/443/2014-DS-PB, BHMZ Programme of Dr.-ErichKrüger-Foundation (Germany) at TU Bergakademie Freiberg, BMBF within the project CryPhys Concept (03 EK3029A).

\section{Notes and references}

1 H. Ehrlich, P. Simon, M. Motylenko, M. Wysokowski, V. V. Bazhenov, R. Galli, A. L. Stelling, D. Stawski, M. Ilan, H. Stöcker, B. Abendroth, R. Born, T. Jesionowski, K. J. Kurzydłowski and D. C. Meyer, J. Mater. Chem. B, 2013, 1, 5092-5099.

2 M. Wysokowski, M. Motylenko, H. Stöcker, V. V. Bazhenov, E. Langer, A. Dobrowolska, K. Czaczyk, R. Galli, A. L. Stelling, T. Behm, Ł. Klapiszewski, D. Ambrożewicz, M. Nowacka, S. L. Molodtsov, B. Abendroth, D. C. Meyer, K. J. Kurzydłowski, T. Jesionowski and H. Ehrlich, J. Mater. Chem. B, 2013, 1, 6469-6476.

3 M. Wysokowski, M. Motylenko, V. V. Bazhenov, D. Stawski, I. Petrenko, A. Ehrlich, T. Behm, Z. Kljajic, A. L. Stelling, T. Jesionowski and H. Ehrlich, Front. Mater. Sci., 2013, 7, 248-260.

4 M. Wysokowski, T. Behm, R. Born, V. V Bazhenov, H. Meißner, G. Richter, K. Szwarc-Rzepka, A. Makarova, 
D. Vyalikh, P. Schupp, T. Jesionowski and H. Ehrlich, Mater. Sci. Eng., C, 2013, 33, 3935-3941.

5 M. Wysokowski, A. Piasecki, V. V Bazhenov, D. Paukszta, R. Born, I. Petrenko and T. Jesionowski, Journal of Chitin and Chitosan Science, 2013, 1, 26-33.

6 X. Yan, J. Li and H. Möhwald, Adv. Mater., 2012, 24, 26632667.

7 X. Yan, J. Blacklock, J. Li and H. Möhwald, ACS Nano, 2012, 6, 111-117.

8 E. Dujardin and S. Mann, Adv. Mater., 2002, 14, 775-788.

9 C. Sanchez, H. Arribart and M. M. G. Guille, Nat. Mater., 2005, 4, 277-288.

10 A.-W. Xu, Y. Ma and H. Cölfen, J. Mater. Chem., 2007, 17, 415-449.

11 H. Ehrlich, Int. Geol. Rev., 2010, 52, 661-699.

12 F. Jun, L. I. Jianghai and C. H. U. Fengyou, Acta Oceanol. Sin., 2009, 28, 87-95.

13 T. L. Cook and D. S. Stakes, Science, 1995, 267, 1975-1979.

14 A.-L. Reysenbach, Y. Liu, A. B. Banta, T. J. Beveridge, J. D. Kirshtein, S. Schouten, M. K. Tivey, K. L. Von Damm and M. A. Voytek, Nature, 2006, 442, 444-447.

15 M. Nidhin, K. J. Sreeram and B. U. Nair, Appl. Surf. Sci., 2012, 258, 5179-5184.

16 C. Ercole, P. Cacchio, A. L. Botta, V. Centi and A. Lepidi, Microsc. Microanal., 2007, 13, 42-50.

17 C. S. Chan, S. C. Fakra, D. C. Edwards, D. Emerson and J. F. Banfield, Geochim. Cosmochim. Acta, 2009, 73, 38073818.

18 R. Hedrich, S. Machill and E. Brunner, Carbohydr. Res., 2013, 365, 52-60.

19 P. U. P. A. Gilbert, M. Abrecht and B. H. Frazer, Rev. Mineral. Geochem., 2005, 59, 157-185.

20 B. Mamet, C. De Ridder, F. Boulvain and D. Gillan, Sediment. Geol., 2000, 137, 107-126.

21 S. Poorni and K. Natarajan, Colloids Surf., B, 2014, 114, 186192.

22 H.-O. Fabritius, C. Sachs, P. R. Triguero and D. Raabe, Adv. Mater., 2009, 21, 391-400.

23 S. Nikolov, M. Petrov, L. Lymperakis, M. Friák, C. Sachs, H.-O. Fabritius, D. Raabe and J. Neugebauer, Adv. Mater., 2010, 22, 519-526.

24 I. M. Weiss and V. Schönitzer, J. Struct. Biol., 2006, 153, 264277.

25 T. Furuhashi, C. Schwarzinger, I. Miksik, M. Smrz and A. Beran, Comp. Biochem. Physiol., Part B: Biochem. Mol. Biol., 2009, 154, 351-371.

26 M. Poulicek, Biochem. Syst. Ecol., 1983, 11, 47-54.

27 K. M. Sherrard, Biol. Bull., 2000, 198, 404-414.

28 M. Florek, E. Fornal, P. Gómez-Romero, E. Zieba, W. Paszkowicz, J. Lekki, J. Nowak and A. Kuczumow, Mater. Sci. Eng., C, 2009, 29, 1220-1226.

29 E. Brunner, P. Richthammer, H. Ehrlich, S. Paasch, P. Simon, S. Ueberlein and K.-H. van Pée, Angew. Chem., Int. Ed., 2009, 48, 9724-9727.

30 M. Bo, G. Bavestrello, D. Kurek, S. Paasch, E. Brunner, R. Born, R. Galli, A. L. Stelling, V. N. Sivkov, O. V Petrova, D. Vyalikh, K. Kummer, S. L. Molodtsov, D. Nowak,
J. Nowak and H. Ehrlich, Int. J. Biol. Macromol., 2012, 51, 129-137.

31 H. Ehrlich, M. Maldonado, K. Spindler, C. Eckert, T. Hanke, R. Born, P. Simon, S. Heinemann and H. Worch, J. Exp. Zool., Part B, 2007, 356, 347-356.

32 H. Ehrlich, M. Krautter, T. Hanke, P. Simon, C. Knieb, S. Heinemann and H. Worch, J. Exp. Zool., Part B, 2007, 308B, 473-483.

33 E. Brunner, H. Ehrlich, P. Schupp, R. Hedrich, S. Hunoldt, M. Kammer, S. Machill, S. Paasch, V. V. Bazhenov, D. V. Kurek, T. Arnold, S. Brockmann, M. Ruhnow and R. Born, J. Struct. Biol., 2009, 168, 539-547.

34 M. Wysokowski, V. V Bazhenov, M. V Tsurkan, R. Galli, A. L. Stelling, H. Stöcker, S. Kaiser, E. Niederschlag, G. Gärtner, T. Behm, M. Ilan, A. Y. Petrenko, T. Jesionowski and H. Ehrlich, Int. J. Biol. Macromol., 2013, 62, 94-100.

35 H. Ehrlich, M. Ilan, M. Maldonado, G. Muricy, G. Bavestrello,

Z. Kljajic, J. L. Carballo, S. Schiaparelli, A. Ereskovsky, P. Schupp, R. Born, H. Worch, V. Bazhenov, D. Kurek, V. Varlamov, D. Vyalikh, K. Kummer, V. V Sivkov, S. L. Molodtsov, H. Meissner, G. Richter, E. Steck, W. Richter, S. Hunoldt, M. Kammer, S. Paasch, V. Krasokhin, G. Patzke and E. Brunner, Int. J. Biol. Macromol., 2010, 47, 132-140.

36 H. Ehrlich, E. Steck, M. Ilan, M. Maldonado, G. Muricy, G. Bavestrello, Z. Kljajic, J. L. Carballo, S. Schiaparelli, A. Ereskovsky, P. Schupp, R. Born, H. Worch, V. V Bazhenov, D. Kurek, V. Varlamov, D. Vyalikh, K. Kummer, V. V Sivkov, S. L. Molodtsov, H. Meissner, G. Richter, S. Hunoldt, M. Kammer, S. Paasch, V. Krasokhin, G. Patzke, E. Brunner and W. Richter, Int. J. Biol. Macromol., 2010, 47, 141-145.

37 H. Ehrlich, P. Simon, W. Carrillo-Cabrera, V. V. Bazhenov,

J. P. Botting, M. Ilan, A. V. Ereskovsky, G. Muricy, H. Worch, A. Mensch, R. Born, A. Springer, K. Kummer, D. V. Vyalikh, S. L. Molodtsov, D. Kurek, M. Kammer, S. Paasch and E. Brunner, Chem. Mater., 2010, 22, 14621471.

38 J. A. Cruz-Barraza, J. L. Carballo, A. Rocha-Olivares, H. Ehrlich and M. Hog, PLoS One, 2012, 7, e42049.

39 H. Ehrlich, O. V Kaluzhnaya, M. V Tsurkan, A. Ereskovsky, K. R. Tabachnick, M. Ilan, A. Stelling, R. Galli, O. V Petrova, S. V Nekipelov, N. Sivkov, D. Vyalikh, R. Born, T. Behm, A. Ehrlich, L. I. Chernogor, S. Belikov, D. Janussen, V. V Bazhenov and G. Wörheide, Proc. R. Soc. Edinburgh, Sect. B: Biol. Sci., 2013, 280, 20130339.

40 H. Ehrlich, O. V Kaluzhnaya, E. Brunner, M. V Tsurkan, A. Ereskovsky, M. Ilan, K. R. Tabachnick, V. V Bazhenov, S. Paasch, M. Kammer, R. Born, A. Stelling, R. Galli, S. Belikov, O. V Petrova, V. V Sivkov, D. Vyalikh, S. Hunoldt and G. Wörheide, J. Struct. Biol., 2013, 183, 474-483.

41 H. Ehrlich, J. K. Rigby, J. P. Botting, M. Tsurkan, C. Werner, P. Schwille, Z. Petrasek, A. Pisera, P. Simon, V. Sivkov, D. Vyalikh, L. S. Molodtsov, D. Kurek, M. Kammer, S. Hunoldt, R. Born, D. Stawski, A. Steinhof and T. GeislerWierwille, Sci. Rep., 2013, 3, 3497. 
42 N. H. Munro, D. W. Green and K. M. McGrath, Chem. Commun., 2013, 49, 3407-3409.

43 N. H. Munro and K. M. McGrath, Dalton Trans., 2011, 40, 9269-9275.

44 G. Falini and S. Fermani, Tissue Eng., 2004, 10, 1-6.

45 W. Ogasawara, W. Shenton, S. A. Davis and S. Mann, Chem. Mater., 2000, 12, 2835-2837.

46 K. Spinde, M. Kammer, K. Freyer, H. Ehrlich, J. N. Vournakis and E. Brunner, Chem. Mater., 2011, 23, 2973-2978.

47 B. Alonso and E. Belamie, Angew. Chem., Int. Ed., 2010, 49, 8201-8204.

48 Y. Chen, X. Zang, J. Gu, S. Zhu and H. Su, J. Mater. Chem., 2011, 21, 6140-6143.

49 J. Chen, H. Su, X. You, J. Gao, W. M. Lau and D. Zhang, Mater. Res. Bull., 2014, 49, 560-565.

50 W. Peng, S. Zhu, W. Wang, W. Zhang, J. Gu, X. Hu, D. Zhang and Z. Chen, Adv. Funct. Mater., 2012, 22, 2072-2080.

51 A. C. A. Wan and B. C. U. Tai, Biotechnol. Adv., 2013, 31, 1776-1785.

52 R. Jayakumar, D. Menon, K. Manzoor, S. V. Nair and H. Tamura, Carbohydr. Polym., 2010, 82, 227-232.

53 A. Anitha, S. Sowmya, P. Kumar, S. Deepthi, K. P. Chennazhi, H. Ehrlich, M. Tsurkan and R. Jayakumar, Prog. Polym. Sci., 2014, 39, 1644-1667.

54 H. Tamura, T. Furuike, S. V. Nair and R. Jayakumar, Carbohydr. Polym., 2011, 84, 820-824.

55 D. Stawski, S. Rabiej, L. Herczyńska and Z. Draczyński, J. Therm. Anal. Calorim., 2008, 93, 489-494.

56 Y. Wang, Y. Chang, L. Yu, C. Zhang, X. Xu, Y. Xue, Z. Li and C. Xue, Carbohydr. Polym., 2013, 92, 90-97.

57 V. Georgieva, D. Zvezdova and L. Vlaev, J. Therm. Anal. Calorim., 2013, 111, 763-771.

58 A. M. Jubb, D. Verreault, R. Posner, L. J. Criscenti, L. E. Katz and H. C. Allen, J. Colloid Interface Sci., 2013, 400, 140-146.

59 J. Y. Kim, G. Magesh, D. H. Youn, J.-W. Jang, J. Kubota, K. Domen and J. S. Lee, Sci. Rep., 2013, 3, 2681.

60 X. Lu, Y. Zeng, M. Yu, T. Zhai, C. Liang, S. Xie, M.-S. Balogun and Y. Tong, Adv. Mater., 2014, 26, 3148-3155.

61 J. Gong, L. Wang, K. Zhao and D. Song, Electrochem. Commun., 2008, 10, 123-126.

62 G. Picasso, M. R. S. Kou, O. Vargasmachuca, J. Rojas, C. Zavala, A. Lopez and S. Irusta, Microporous Mesoporous Mater., 2014, 185, 79-85.

63 K. Sivula, R. Zboril, F. Le Formal, R. Robert, A. Weidenkaff, J. Tucek, J. Frydrych and M. Grätzel, J. Am. Chem. Soc., 2010, 132, 7436-7744.
64 M. Wu, X.-M. Xia, C. Cui, P. Yu, Y. Zhang, L. Liu, R.-X. Zhuo and S.-W. Huang, J. Mater. Chem. B, 2013, 1, 1687.

65 J. Singh, M. Srivastava, J. Dutta and P. K. Dutta, Int. J. Biol. Macromol., 2011, 48, 170-176.

66 J. Huang and Z. Sun, Chin. J. Geochem., 2008, 27, 150-156.

67 X. Fei, Z. Shao and X. Chen, J. Mater. Chem. B, 2013, 1, 213.

68 Y. Gu, X. Liu, T. Niu and J. Huang, Chem. Commun., 2010, 46, 6096-6098.

69 M. Nidhin, M. Vedhanayagam, S. Sangeetha, M. S. Kiran, S. S. Nazeer, R. S. Jayasree, K. J. Sreeram and B. U. Nair, Sci. Rep., 2014, 4, 5968.

70 X. C. Jiang, a. B. Yu, W. R. Yang, Y. Ding, C. X. Xu and S. Lam, J. Nanopart. Res., 2009, 12, 877-893.

71 S. Hamada and E. Matijević, J. Colloid Interface Sci., 1981, 84, 274-277.

72 W. Wang, J. Y. Howe and B. Gu, J. Phys. Chem. C, 2008, 112, 9203-9208.

73 D. L. A. de Faria, S. V. Silva and M. T. de Oliveira, J. Raman Spectrosc., 1997, 28, 873-878.

74 F. Froment, A. Tournié and P. Colomban, J. Raman Spectrosc., 2008, 39, 560-568.

75 J. De Gelder, K. De Gussem, P. Vandenabeele and L. Moens, J. Raman Spectrosc., 2007, 38, 1133-1147.

76 I. V. Chernyshova, M. F. Hochella and A. S. Madden, Phys. Chem. Chem. Phys., 2007, 9, 1736-1750.

77 H. Zhang, J. Song and C. Liu, Ind. Eng. Chem. Res., 2013, 52, 7403-7412.

78 V. Dhanasekaran, S. Anandhavelu, E. K. Polychroniadis and T. Mahalingam, Mater. Lett., 2014, 126, 288-290.

79 A. P. Grosvenor, B. A. Kobe, M. C. Biesinger and N. S. McIntyre, Surf. Interface Anal., 2004, 36, 1564-1574.

80 C. L. Huang, H. Y. Zhang, Z. Y. Sun and Z. M. Liu, Sci. China: Chem., 2010, 53, 1502-1508.

81 Y. Wang, B. Li, Y. Zhou, D. Jia and Y. Song, Polym. Adv. Technol., 2011, 22, 1681-1684.

82 J. R. B. Gomes, M. Jorge and P. Gomes, J. Chem. Thermodyn., 2014, 73, 121-129.

83 M. Zhu, Y. Wang, D. Meng, X. Qin and G. Diao, J. Phys. Chem. C, 2012, 116, 16276-16285.

84 G. Tong, J. Guan and Q. Zhang, Mater. Chem. Phys., 2011, 127, 371-378.

85 S. Shivakumara, T. R. Penki and N. Munichandraiah, Mater. Lett., 2014, 131, 100-103.

86 S. Wang, Y. Wang, H. Zhang, X. Gao, J. Yang and Y. Wang, RSC Adv., 2014, 4, 30840-30849. 